\title{
Fertilization of an oligotrophic lake with a deep chlorophyll maximum: predicting the effect on primary productivity
}

\author{
Howard P. Gross, Wayne A. Wurtsbaugh, Chris Luecke, and Phaedra Budy
}

\begin{abstract}
We investigated how epilimnetic fertilization would affect chlorophyll levels and light penetration of oligotrophic sockeye salmon (Oncorhynchus nerka) lakes and how the resulting self-shading would affect primary production of the prominent deep chlorophyll maxima (DCM) of the lakes. Epilimnetic nutrient additions to large mesocosms $\left(330 \mathrm{~m}^{3}\right)$ in Redfish Lake, Idaho, increased levels of primary productivity and chlorophyll $a$ but decreased Secchi depths and light available in the metalimnion and hypolimnion. Redfish Lake and other Sawtooth Valley (Idaho) lakes had DCM in which the mean chlorophyll $a$ peaks were $240-1000 \%$ of mean epilimnetic chlorophyll $a$ concentrations. The DCM existed at low light levels and accounted for $36-72 \%$ of the lakes' primary production. Simulations using photosynthesis-irradiance $(P-I)$ curves demonstrated that fertilization would increase predicted water column primary production by $75-101 \%$. Most of this increase occurred in the epilimnion, with only a slight decrease occurring in the DCM as the result of increased shading.

Résumé : Nous avons cherché à déterminer comment la fertilisation épilimnétique pouvait influer sur les concentrations de chlorophylle et la pénétration de la lumière dans les lacs oligotrophes fréquentés par le saumon sockeye (Oncorhynchus nerka) et comment l'ombre autogénérée qui en résulte influe sur la production primaire des maximums de chlorophylle dans la couche profonde (MCP) dominants dans ces lacs. Des ajouts d'éléments nutritifs dans l'épilimnion dans de grands mésocosmes $\left(330 \mathrm{~m}^{3}\right)$ du lac Redfish en Idaho ont augmenté le degré de production primaire et la concentration de chlorophylle $a$, mais ont diminué la profondeur de transparence au disque de Secchi et la lumière disponible dans le métalimnion et l'hypolimnion. Le lac Redfish et d'autres lacs de la vallée Sawtooth, en Idaho, présentaient des MCP dans lesquels les maximums de la concentration moyenne de la chlorophylle $a$ équivalaient à $240-1000 \%$ de la concentration épilimnétique moyenne de chlorophylle $a$. Les MCP existaient à des faibles degrés de luminosité et expliquaient 36-72\% de la productivité primaire des lacs. Des simulations avec des courbes de photosynthèse-irradiation $(P-I)$ ont montré que la fertilisation augmenterait la production primaire prévue dans la colonne d'eau de 75 à $101 \%$. La plus grande partie de cette augmentation est survenue dans l'épilimnion et seule une légère diminution des MCP a été observée à la suite de l'augmentation de l'ombre.

[Traduit par la Rédaction]
\end{abstract}

\section{Introduction}

Managers have used lake fertilization to increase the productivity of sockeye salmon (Oncorhynchus nerka) rearing lakes in North America, primarily for commercial purposes (Stockner 1987; Kyle et al. 1988). This approach attempts to enhance trophic transfer throughout the limnetic food chain: increases in a lake's nutrient load cause increases in the productivity of the phytoplankton community, which leads to increases in zooplankton and, ultimately, sockeye production.

We evaluated lake fertilization as a tool to help prevent the extinction of the endangered Snake River sockeye salmon (Budy et al. 1994; Gross et al. 1994; Gross 1995; Luecke et al. 1996). Owing to a drastic decline ( $>99 \%)$ in the numbers of anadromous sockeye salmon in the Sawtooth Valley lakes, central Idaho, U.S.A., resource managers began a hatchery

Received February 23, 1996. Accepted October 10, 1996. J13319

H.P. Gross, ${ }^{1}$ W.A. Wurtsbaugh, C. Luecke, and P. Budy. Department of Fisheries and Wildlife, Utah State University, Logan, UT 84322-5210, U.S.A.

1 Present address: SWCA Environmental Consultants, 56 West 400 South, Suite 201, Salt Lake City, UT 84101, U.S.A. e-mail: hgross96@aol.com broodstock program to propagate more sockeye salmon than would overwise survive in the lakes (Bevan et al. 1994). As presmolts from this broodstock program are released into the Sawtooth Valley lakes, managers may use lake fertilization to increase the fish's growth and survival rates.

The Sawtooth Valley lakes have deep chlorophyll maxima (DCM) (Budy et al. 1995) that may be affected by lake fertilization. Chlorophyll $a$ concentrations in these lakes can be up to 10 times greater in the metalimnia and hypolimnia than in the epilimnia (Steinhart et al. 1994).

DCM in lakes and oceans have varying characteristics that suggest multiple processes contributing to their formation and maintenance (Steele 1964; Anderson 1969; Hobson and Lorenzen 1972). DCM occur in or below the thermocline where light, temperature, and turbulence are low, but nutrients are relatively rich (Moll and Stoermer 1982). Some investigators (e.g., Shortreed and Stockner 1990) maintain that most of the DCM is controlled by differential sinking rates of algal cells generated in the epilimnion, while others (e.g., Fee 1976) conclude that the DCM is generated in situ by substantial levels of primary production. Investigators must exercise caution when assigning ecological significance to the DCM because phytoplankton will often increase pigment production under the low-light conditions of deeper waters (Steele 1964; Hobson and Lorenzen 1972; Kiefer et al. 1976). 
Table 1. Physical and morphometric characteristics of the Sawtooth Valley lakes.

\begin{tabular}{lccccc}
\hline Lake & $\begin{array}{c}\text { Surface } \\
\text { area } \\
\left(\mathrm{km}^{2}\right)\end{array}$ & $\begin{array}{c}\text { Mean } \\
\text { depth } \\
(\mathrm{m})\end{array}$ & $\begin{array}{c}\text { Max. } \\
\text { Depth } \\
(\mathrm{m})\end{array}$ & $\begin{array}{c}\text { Drainage } \\
\text { area } \\
\left(\mathrm{km}^{2}\right)\end{array}$ & $\begin{array}{c}\text { Mean summer } \\
\text { Secchi depth, } \\
1993(\mathrm{~m})\end{array}$ \\
\hline Redfish & 6.15 & 44 & 91 & 108.1 & 11.9 \\
Alturas & 3.38 & 32 & 53 & 75.7 & 10.4 \\
Pettit & 1.62 & 28 & 52 & 27.4 & 13.2 \\
Stanley & 0.81 & 13 & 26 & 39.4 & 7.3 \\
Yellow Belly & 0.73 & 14 & 26 & 30.4 & 9.2 \\
\hline
\end{tabular}

In some sockeye salmon rearing lakes, juvenile sockeye may primarily reside at metalimnetic depths during part of the growing season owing to temperature limitations (Foerster 1968), consuming a large portion of the metalimnetic zooplankton standing stock (LeBrausser et al. 1978; Shortreed and Stockner 1990). This reduction in metalimnetic zooplankton and corresponding reduction in grazing rate on phytoplankton may also contribute to the maintenance of the DCM.

The DCM in the Sawtooth Valley lakes are located at depths where the light levels are near or below $1 \%$ of surface light. Although this light level is nominally given as the bottom of the photic zone, substantial primary production has been measured at lower light levels (Anderson 1969). Increases in phytoplankton, which would result from lake fertilization, should decrease light available in the DCM and lead to a compression of the photic zone (Goldman 1988). Thus, we were interested in the effect this shading could have on the phytoplankton assemblage in the DCM and resultant effects on water column primary production.

Here we describe the DCMs relative contribution to overall lake primary production. We also investigate the possibility of the DCM being an artifact of increases in pigment production under low-light conditions. Finally, we determine the effect of epilimnetic nutrient additions on primary production in the epilimnion and in the DCM. To accomplish these goals, we implemented a lake sampling program, conducted fertilization experiments in large-scale mesocosms, and constructed a primary productivity prediction model. Our work concentrated on one of the Sawtooth Valley lakes, Redfish Lake, because it is the focus of the sockeye salmon recovery program. Data from other Sawtooth Valley lakes are presented for emphasis of certain findings.

\section{Study area}

The five study lakes are located in the Sawtooth National Recreation Area in south-central Idaho $\left(44^{\circ} \mathrm{N}, 115^{\circ} \mathrm{W}\right)$ at elevations between 1985 and $2157 \mathrm{~m}$ (Table 1). The lakes drain the east sides of the pristine, granitic Sawtooth and Smoky Mountains. These deep, steep-sided lakes were formed behind large moraines deposited by glaciers during the Pleistocene.

Nutrient levels in the lakes are low: mean summer total nitrogen (TN) and total phosphorus (TP) concentrations in their epilimnia were 65-95 and 6.5-8.6 $\mu \mathrm{g} / \mathrm{L}$, respectively. Correspondingly, water clarity is high, with Secchi depths ranging up to $19 \mathrm{~m}$ (Steinhart et al. 1994). Phytoplankton growth in Redfish Lake is limited primarily by nitrogen and secondarily by phosphorus, both in the epilimnion and in the DCM (Gross 1995). Macrophyte abundance is low. The lakes and their watersheds are highly prized for their recreational and aesthetic values.

Redfish Lake has a very low zooplankton biomass, dominated by Bosmina longirostris and Holopedium gibberum, with small contributions from Daphnia rosea, Polyphemus pediculus, Epischura nevadensis, and at least two species of cyclopoid copepods (Budy et al. 1995). The fish community includes sockeye and kokanee salmon (both $O$. nerka), bull trout (Salvelinus confluentus), northern squawfish (Ptychocheilus oregonensis), and rainbow trout (Oncorhynchus mykiss) (Beauchamp et al. 1993).

\section{Methods}

\section{Lake sampling}

Sampling of Sawtooth Valley lakes in 1993 began in March when all of the lakes were sampled through a hole sawed through 50-70 cm of ice. Redfish, Alturas, Pettit, and Stanley lakes were sampled biweekly from mid-May (ice-out) until the beginning of October, and then again in November. Yellow Belly Lake was sampled in March and monthly from June through September.

A Hydrolab $\mathrm{H} 2 \mathrm{O}^{\circledR}$ multiparameter water-quality data transmitter was used to take vertical profiles of temperature. Vertical profiles of light extinction were measured using a LI-COR Model LI-1000 datalogger, a deck cell, and an underwater spherical sensor that measured photosynthetic active radiation (PAR; 400-700 nm). Measurements were taken at 2-m intervals until $36 \mathrm{~m}$ or to the bottom of the shallower lakes. The light extinction coefficient (Wetzel 1983) was then calculated and used to compute the depth where $1 \%$ of surface light remained. Water transparency measurements were made with a $25 \mathrm{~cm}$ diameter Secchi disk.

In most of the lakes, chlorophyll samples were collected biweekly from the epilimnion with a tube sampler at three stations. These stations were separated by 200-500 m near the deepest part of each lake. At the central index station additional samples were taken at the $1 \%$ light level. At monthly intervals, samples from 5 to 13 other depths were collected at the index station. For chlorophyll analysis, two 50 -mL aliquots per sample were filtered through $0.45-\mu \mathrm{m}$ cellulose acetate membrane filters. (Earlier size-fractionation analyses using Nucleopore filters demonstrated that $0.45-\mu \mathrm{m}$ filters retained $83-97 \%$ of the chlorophyll that was retained by $0.1-\mu \mathrm{m}$ filters (Budy et al. 1995).) Filters were placed into $6 \mathrm{~mL}$ of $100 \%$ methanol in the dark for 24-48 $\mathrm{h}$ to extract chlorophyll $a$. The extracts were then analyzed before and after acidification (Holm-Hansen and Riemann 1978) using a Turner model 111 fluorometer. Corrections were made for phaeopigments. The fluorometer was calibrated using commercial chlorophyll $a$ standards that were verified spectrophotometrically.

Phytoplankton samples were collected monthly from the epilimnion and 1\% light level and preserved using Lugol's iodine solution. Additional epilimnetic samples were collected at biweekly intervals from some lakes. A 50 - or $100-\mathrm{mL}$ aliquot from each sample was filtered through a $0.45-\mu \mathrm{m}$ mixed-ester filter (Millipore ${ }^{\circledR}$ HAWP), cleared, and permanently mounted according to the method of Crumpton (1987). Cells were counted in a minimum of 10 fields per slide at $400 \times$; the dimensions of a minimum of 10 individuals in each taxon were measured to calculate biovolume (Wetzel and Likens 1991). Phytoplankton were taxonomically classified as follows: Cyanobacteria (blue-green algae), Chlorophyta (green algae), Chrysophyta (primarily Dinobryon sp.), Bacillariophyta (diatoms), and Dinophyta (primarily Peridinium sp.).

In situ primary production rates (PPR) of phytoplankton were measured with the ${ }^{14} \mathrm{C}$-technique (Wetzel and Likens 1991). Measurements were made on three dates in Redfish and Pettit lakes, and once in Stanley and Alturas lakes. Water from each of eight or nine depths was placed into three $25-\mathrm{mL}$ glass scintillation vials, taking 
care not to expose the plankton to direct sunlight. Each vial was inoculated with $80 \mu \mathrm{L}$ of $25 \mu \mathrm{Ci} / \mathrm{mL}$ of ${ }^{14} \mathrm{CHO}_{3}-$. To measure nonphotosynthetic ${ }^{14} \mathrm{C}$ uptake, we inoculated one vial from each depth with $150 \mu \mathrm{L}$ of a saturated solution of Diuron (dichlorophenyldimethylurea; DCMU), a photosynthetic inhibitor. The vials were resuspended in the water column in clear acrylic plastic tubes hung from an incubation line. Incubations were normally conducted from 10:00 to 14:00 (Mountain Standard Time). After the incubation, the vials were kept in the dark and within $2 \mathrm{~h}$ the entire contents of each vial were filtered through $0.45-\mu \mathrm{m}$ cellulose nitrate filters and rinsed with $0.01 \mathrm{M} \mathrm{HCl}$. They were then air-dried and subsequently counted by liquid scintillation spectrometry using Readysafe ${ }^{\circledR}$ cocktail. Production rates were calculated by subtracting carbon uptake in the DCMU treatments from the light treatments. Dissolved inorganic carbon was estimated from $\mathrm{pH}$ and temperature, and alkalinity measurements were determined with the Gran procedure (Wetzel and Likens 1991). Productivity in the water column was partitioned into that occurring in the epilimnion and in the lower strata. Because the lakes were not clearly stratified for much of the summer, we used a nominal depth stratum of $0-7.5 \mathrm{~m}$ for calculating the production that occurred in the epilimnion.

\section{Limnocorral experiment}

Nutrient addition experiments took place in Redfish Lake in six cylindrical mesocosms (limnocorrals, designed by Aquatic Research Instruments, Seattle, Wash.) over an 11 -week period. The $330-\mathrm{m}^{3}$ limnocorrals were $5 \mathrm{~m}$ in diameter and approximately $17 \mathrm{~m}$ deep with open tops floated above the lake surface. They were constructed with weighted curtains of impermeable, fiber-reinforced polyethylene. The limnocorrals were unfurled slowly $(12 \mathrm{~h})$ through the water column with the bottoms open; thus, the initial conditions were similar to those in the lake. Once filled, SCUBA divers tied the bottoms closed. Each limnocorral was randomly assigned one of three nutrient treatments $(n=2)$ :

(1) controls, which received no nutrient additions (CNTL),

(2) low levels of nitrogen $(\mathrm{N})$ and phosphorus (P) additions (LOW), and

(3) high levels of $\mathrm{N}$ and $\mathrm{P}$ additions (HIGH).

At the start of the experiment, on 29 June, mean total P (TP) and total N (TN) concentrations in the limnocorrals were $5.6 \mu \mathrm{g} / \mathrm{L}$ (range $5.1-5.9 \mu \mathrm{g} / \mathrm{L}$ ) and $67 \mu \mathrm{g} / \mathrm{L}$ (range $63-76 \mu \mathrm{g} / \mathrm{L}$ ), respectively. In the LOW nutrient treatment we increased $\mathrm{P}$ by $75 \%$ and $\mathrm{N}$ by $125 \%$ over the 11-week experiment (i.e., $4.2 \mu \mathrm{g} \mathrm{P} / \mathrm{L}$ and $84 \mu \mathrm{g} \mathrm{N} / \mathrm{L}$ were added). In the $\mathrm{HIGH}$ nutrient treatment $\mathrm{P}$ and $\mathrm{N}$ concentrations were increased by 150 and $250 \%$, respectively $(8.4 \mu \mathrm{g} \mathrm{P} / \mathrm{L}$ and $168 \mu \mathrm{g} \mathrm{N} / \mathrm{L})$. Nutrients were added in the form of $\left(\mathrm{NH}_{4}\right)_{2} \mathrm{HPO}_{4}$ and $\mathrm{NH}_{4} \mathrm{NO}_{3}$, at a 20:1 mass TN:TP ratio. The high TN:TP ratio was used to reduce the likelihood of stimulating nitrogen-fixing cyanobacteria (Schindler 1977; Stockner and Shortreed 1988). Weekly, nutrient solutions were stirred into each limnocorral at the surface. To promote rapid initial growth of the plankton community, $40 \%$ of the nutrients were added during the first week of the experiment; the remaining $60 \%$ were added in equal parts over the following 10 weeks.

Because the experiment was also designed to determine whether zooplankton and fish growth could be enhanced by nutrient additions, we added 25 native young-of-the-year kokanee in lieu of endangered sockeye salmon to each of the limnocorrals, for a stocking density of $1.3 \mathrm{fish} / \mathrm{m}^{2}$. The results of the nutrient additions on zooplankton and fish growth are reported in Budy et al. (1994).

We monitored chlorophyll $a$, primary production, and light in each limnocorral. Monitoring was conducted 7 days after a nutrient addition and immediately before the subsequent addition. Samples were collected weekly for chlorophyll $a$ analysis from the epilimnion ( 0 to 4,5 , or $6 \mathrm{~m}$, deepening during the summer) with a depthintegrating vinyl tube. Biweekly, we collected additional chlorophyll samples from the metalimnion and near the bottom of the limnocorral with a 4-L Van Dorn bottle. At 1, 4, and 8 weeks of the experiment,
Table 2. Chlorophyll $a$ concentrations (Chl. $a, \mu \mathrm{g} / \mathrm{L}$ ) in the epilimnion and the deep chlorophyll maximum (DCM) peaks in the Sawtooth Valley lakes during June-October 1993.

\begin{tabular}{lcccc}
\hline Lake & $\begin{array}{c}\text { Mean } \\
\text { epilimnetic } \\
\text { Chl. } a\end{array}$ & $\begin{array}{c}\text { Mean } \\
\text { DCM } \\
\text { peak }\end{array}$ & $\begin{array}{c}\text { DCM } \\
\text { peak } \\
\text { range }\end{array}$ & $\begin{array}{c}\text { \% increase in mean } \\
\text { DCM peak over mean } \\
\text { epilimnetic Chl. } a\end{array}$ \\
\hline Redfish & 0.6 & 3.1 & $2.2-4.8$ & 420 \\
Alturas & 0.8 & 2.7 & $2.0-3.4$ & 240 \\
Pettit & 0.5 & 3.3 & $2.0-4.4$ & 560 \\
Stanley & 1.1 & 2.4 & $1.6-4.5$ & 120 \\
Yellow Belly & 0.6 & 6.6 & $2.6-8.2$ & 1000 \\
\hline
\end{tabular}

${ }^{14} \mathrm{C}$ primary productivity measurements were made at five depths using the methods described above. Additional depths were sampled for chlorophyll $a$ analysis concurrent with the primary productivity measurements. Water transparency measurements were made weekly with a $25-\mathrm{cm}$ black and white Secchi disk. Vertical profiles of light intensity were measured every $2-4$ weeks as described above, except that measurements were taken at $1-\mathrm{m}$ intervals from depths of 0 to $17 \mathrm{~m}$.

\section{Primary production prediction modelling}

Because the DCM peaked below $20 \mathrm{~m}$ in Redfish Lake, the 17-m bottom boundary of the limnocorrals prevented us from determining, in situ, what effects shading caused by epilimnetic fertilization would have on the DCM. Therefore, we used a modelling approach to (i) simulate the decline in PPR in the DCM that might result from shading associated with fertilization; (ii) compare the reduction in PPR in the DCM with the enhancement of PPR in the epilimnion; and (iii) compare total simulated water column PPR under fertilized and unfertilized conditions.

To predict PPR depth profiles for Redfish Lake under the altered light and chlorophyll conditions expected with fertilization, we used photosynthesis-irradiance curves ( $P-I$ curves; Reynolds 1984). These curves relate irradiance $(I)$ to photosynthetic rate $\left(P^{\mathrm{B}}\right.$, normalized to chlorophyll $a$ biomass). They were produced using PPR, chlorophyll $a$, and irradiance data collected during the lake sampling and ${ }^{14} \mathrm{C}$ measurements. The average depth-specific irradiance for the duration of each ${ }^{14} \mathrm{C}$ measurement was used. Data from six of the eight PPR profiles measured in the Sawtooth Valley lakes were used; two profiles were excluded (Redfish Lake, 4 July 1993, and Pettit Lake, 7 August 1993) owing to incomplete data.

Parameters of the $P-I$ curve, such as the initial slope of the lightlimited portion of the curve $(\alpha)$ and the maximum photosynthetic rate $\left(P_{\mathrm{m}}^{\mathrm{B}}\right)$, are affected by factors such as temperature, nutrient conditions, and the species comprising the algal community. In addition, photoinhibition (characterized by $\beta$ ) can occur above a threshold light intensity $\left(I_{\mathrm{T}}\right) ; \beta$ and $I_{\mathrm{T}}$ also can vary with environmental conditions.

To partially account for the variations of the $P-I$ curves' parameters with depth, we used two $P-I$ curves. We separated our samples into two groups using the bottom of the thermocline, which provides an impediment to mixing, as the delineator (Platt et al. 1982). The $P-I$ curve for samples from below the thermocline was fit using eq. 8 from Jassby and Platt (1976), which is based on two parameters, $\alpha$ and $P_{\mathrm{m}}^{\mathrm{B}}$ :

(1) $\quad P_{z}^{\mathrm{B}}=P_{\mathrm{m}}^{\mathrm{B}} \cdot \tanh \left(\alpha I_{z} / P_{\mathrm{m}}^{\mathrm{B}}\right)$

where $P_{z}^{\mathrm{B}}$ is the $P^{\mathrm{B}}$ at depth $z$ and $I_{z}$ is the light intensity at depth $z$. (PPR profile predictions were also attempted using two different linear $P-I$ models for below the thermocline; the results varied by $0.3-4.1 \%$ from those derived using the Jassby and Platt (1976) model.) The samples above the bottom of the thermocline were fit using the method of Neale and Richerson (1987), which includes $\beta$ and $I_{\mathrm{T}}$, thus accounting for photoinhibition, which was frequently observed in the shallower depths of the Sawtooth Valley lakes: 
Fig. 1. Chlorophyll a concentration $(\mu \mathrm{g} / \mathrm{L})$ (solid line) and temperature $\left({ }^{\circ} \mathrm{C}\right)$ (dotted line) profiles for Redfish Lake, 1993. When present, an asterisk represents the $1 \%$ light level.
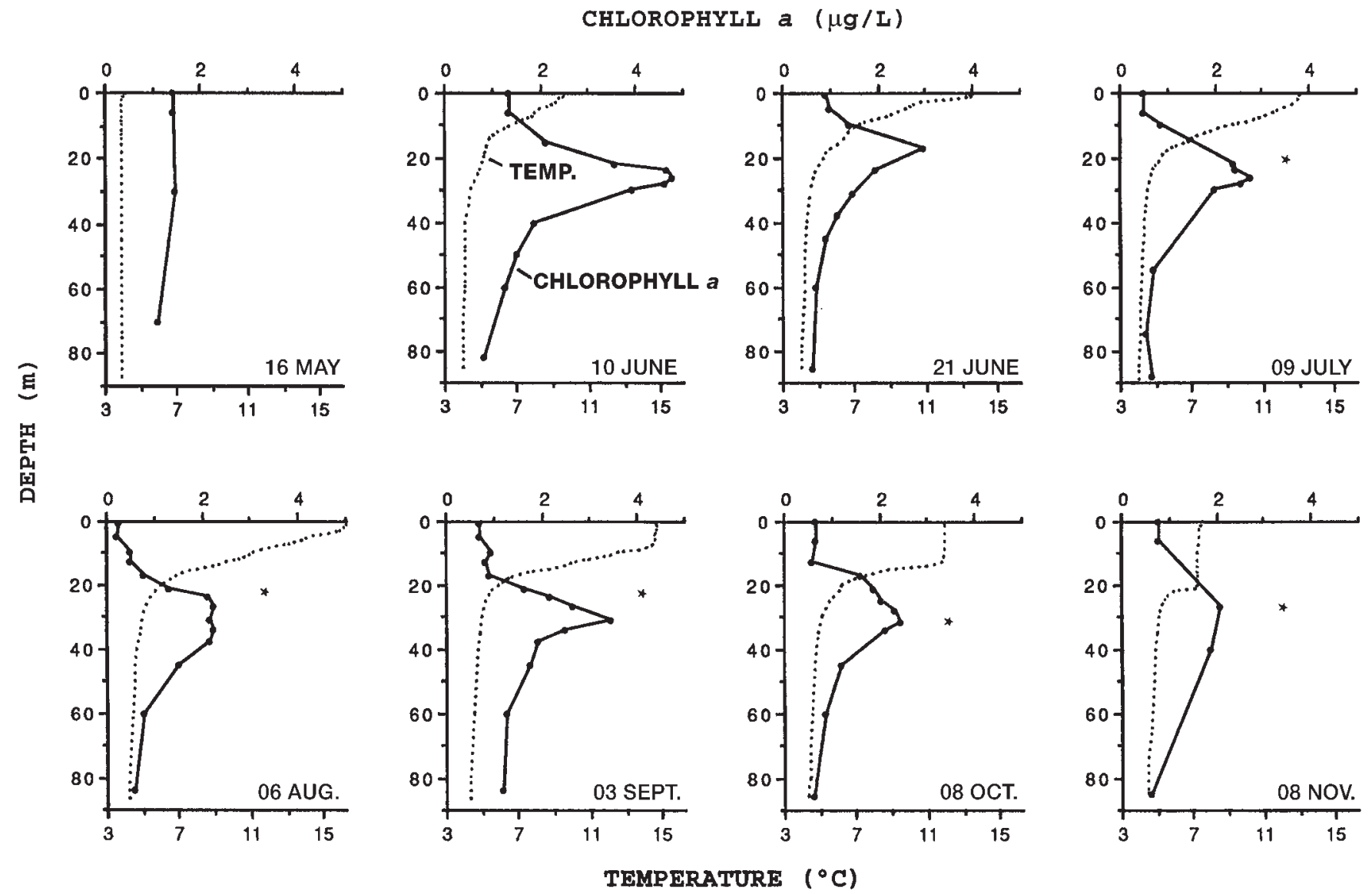

(2) $\quad P_{z}^{\mathrm{B}}=P_{\mathrm{m}}^{\mathrm{B}} \tanh \left(\alpha I_{z} / P_{\mathrm{m}}^{\mathrm{B}}\right) * \mathrm{e}^{-\beta^{* c}}$

where $c=0$ if $I_{z} \leq I_{\mathrm{T}}$ and $c=I_{z}-I_{\mathrm{T}}$ if $I_{z}>I_{\mathrm{T}}$.

The parameters for the $P-I$ curves were derived using the primary productivity, chlorophyll, and light data from the lake sampling program and Gauss-Newton nonlinear regressions (NLIN procedure; SAS Institute Inc. 1988).

The $P-I$ curves were then used to predict and compare vertical primary productivity profiles under fertilized and unfertilized conditions. Predictions for unfertilized conditions were made using light and chlorophyll levels observed in the lake. Predictions for PPR profiles under fertilized conditions were based on the following alterations of observed chlorophyll and light levels:

(1) The chlorophyll levels in the top $17 \mathrm{~m}$ (depths of $0.5,5,10,13$, and $17 \mathrm{~m}$ ) were boosted over values observed in the lake by the increases we saw in the limnocorrals owing to the LOW levels of nutrient additions. The LOW level was chosen because it most closely resembled levels that would be used for a whole-lake fertilization.

(2) Light intensity at each depth was computed using the following equation, which modifies the ambient light level in the lake to include the shading caused by increases in phytoplankton resulting from the nutrient treatments:

$$
I_{z}=I_{0} \cdot\left(\mathrm{e}^{-\mathrm{LE}_{\text {trt }} \cdot z_{1}}\right) \cdot\left(\mathrm{e}^{-\mathrm{LE}_{\text {cnt }} \cdot z_{1}}\right)^{-1} \cdot\left(\mathrm{e}^{-\mathrm{LE}_{\text {lake }} \cdot z_{2}}\right)
$$

where $I_{z}$ is the light intensity in water at depth $z, I_{0}$ is the light intensity in water at depth $0, \mathrm{LE}_{\mathrm{trt}}$ is the mean light extinction coefficient in nutrient treatments (e.g., $\mathrm{LE}_{\text {low }}$ or $\mathrm{LE}_{\text {high }}$ ), $\mathrm{LE}_{\text {cntl }}$ is the mean light extinction coefficient in CNTL treatments, and $\mathrm{LE}_{\text {lake }}$ is the light extinction coefficient in the lake. For $z=0-17 \mathrm{~m}, z=z_{1}=z_{2}$. For $z>$ $17 \mathrm{~m}, z=z_{2}, z_{1}=17 \mathrm{~m}$. LE $\mathrm{trt}_{\text {trt }}$ and $\mathrm{LE}_{\mathrm{cntl}}$ were selected to represent the levels of shading observed in the limnocorrals (the greater the difference between $\mathrm{LE}_{\text {trt }}$ and $\mathrm{LE}_{\mathrm{cnt}}$, the greater the level of shading). Thus, by using recorded light extinction coefficients representing the upper, intermediate, and lower levels of shading observed in the limnocorrals, we tested the sensitivity of the shading parameter.

This approach assumes that all of the added nutrients remained in the top $17 \mathrm{~m}$ of the water column, stimulating the phytoplankton there. In the lake, some of these nutrients would be transported to the DCM through sedimentation and other mixing processes, possibly stimulating phytoplankton growth there (depending on whether this layer is light and (or) nutrient limited).

\section{Results}

\section{Lake sampling}

Deep chlorophyll maxima (DCM) existed in the Sawtooth Valley lakes during the ice-free stratified season (Fig. 1). In midMay, Redfish Lake was isothermal and chlorophyll levels were nearly homogenous from 0 to $70 \mathrm{~m}$, indicating that the lake mixed to the bottom in 1993. By 10 June, a DCM was observable, and it persisted through November, when the thermocline began to erode with the approach of fall overturn. The DCM peak was located below the thermocline, near and frequently below the 1\% light level (Fig. 1). Similar DCM patterns occurred in the other Sawtooth Valley lakes (Budy et al. 1995; Gross 1995). The peak levels of chlorophyll $a$ in the DCM of the Sawtooth Valley lakes from June to October 1993 were 120-1000\% higher than those in the epilimnia (Table 2). 
Fig. 2. Mean chlorophyll $a$ concentration $(\mu \mathrm{g} / \mathrm{L})$ in the epilimnion $(n=3)$ and at the $1 \%$ light level $(n=2)$ in Redfish Lake, 1993 . Vertical bars show range.

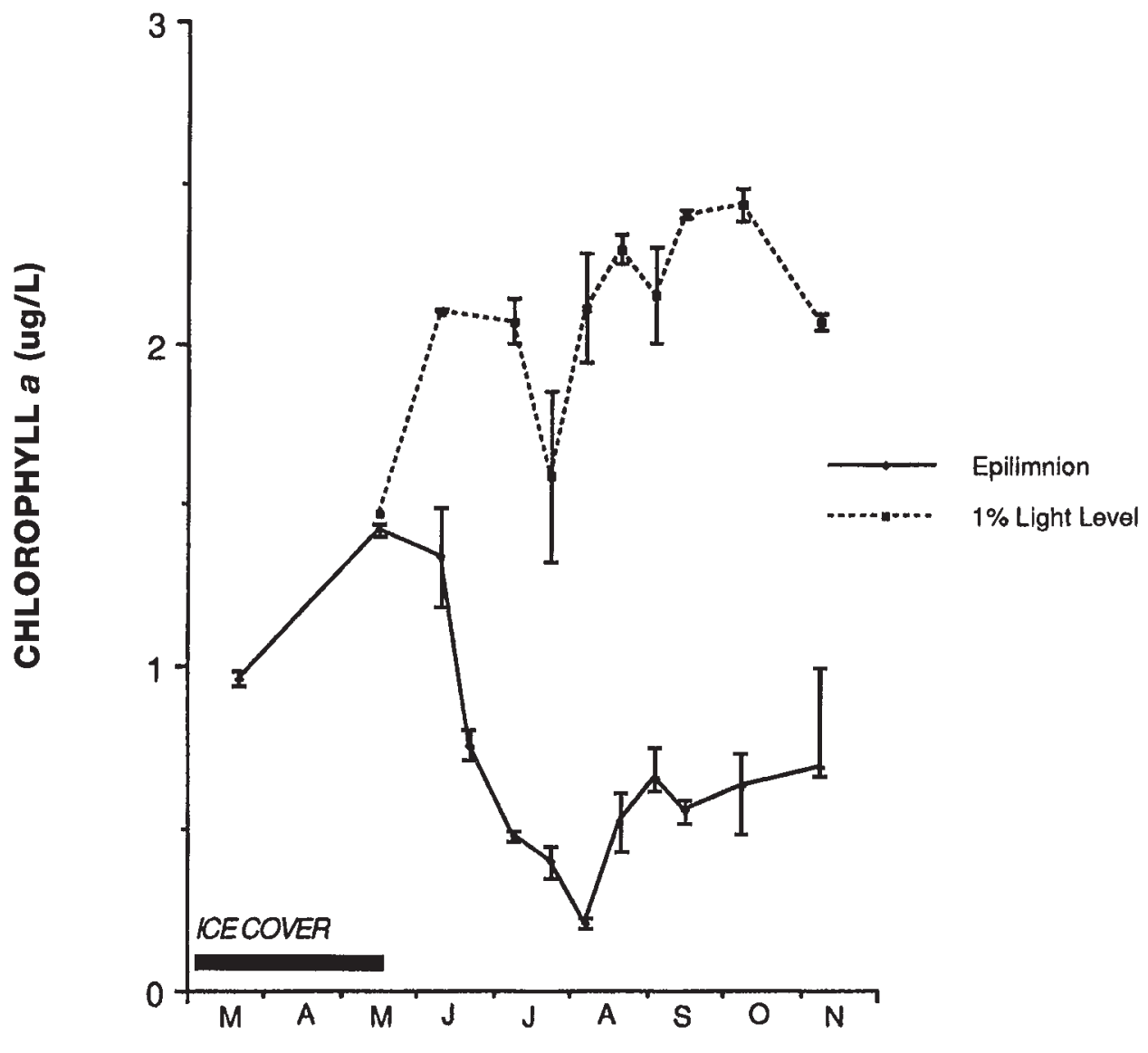

\section{MONTH (1993)}

Fig. 3. Seasonal changes in the biovolumes of different phytoplankton taxa in Redfish Lake, 1993: (a) epilimnetic water and (b) at the 1\% light level. $0.6 \mathrm{~m}$ 1\% Light Level
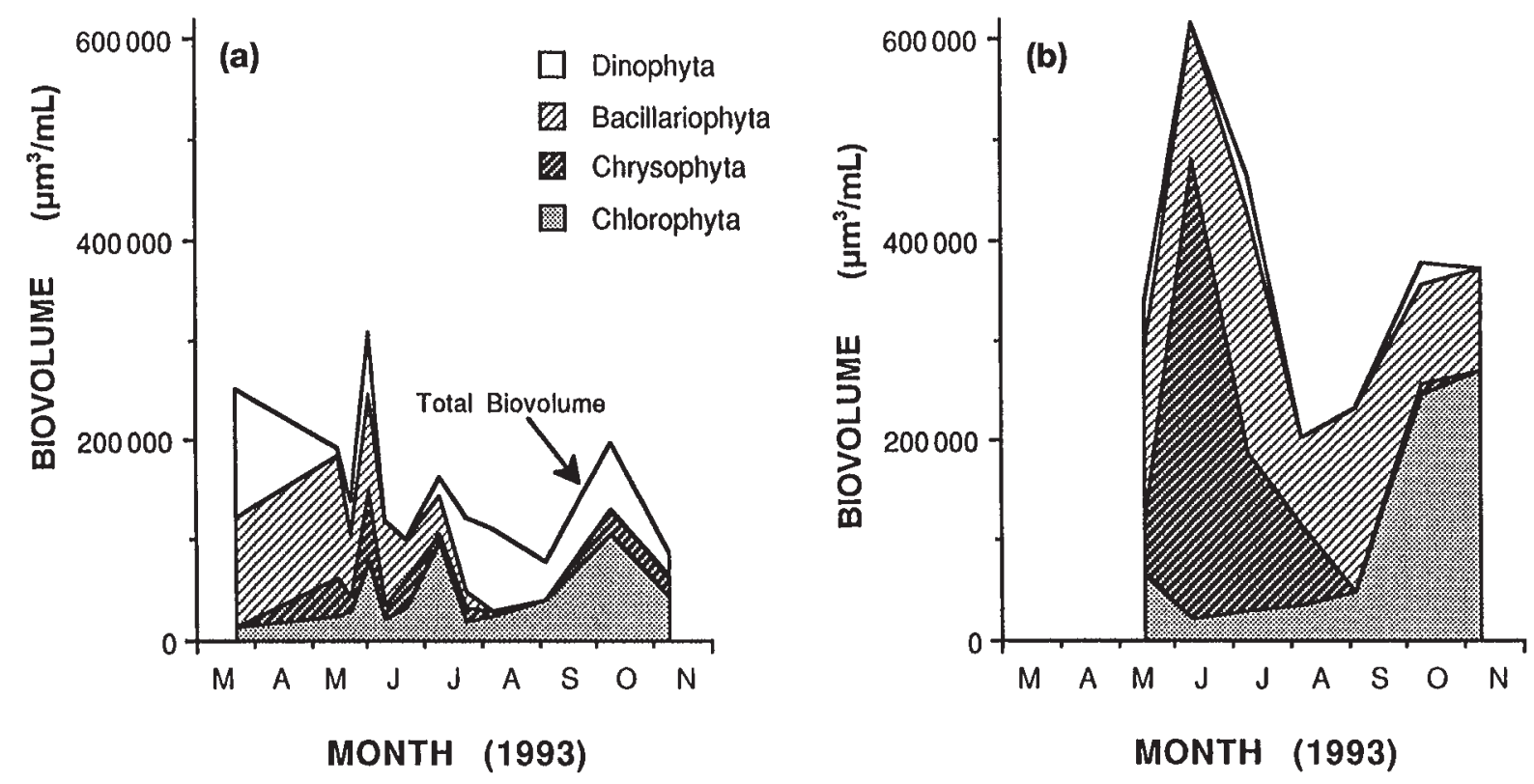
Fig. 4. Vertical profiles of primary productivity (PPR) and temperature in the Redfish, Pettit, Alturas, and Stanley lakes in 1993. Mean and range of duplicate measurements are shown. Curves for PPR are fit with spline functions.

PRIMARY PRODUCTIVITY
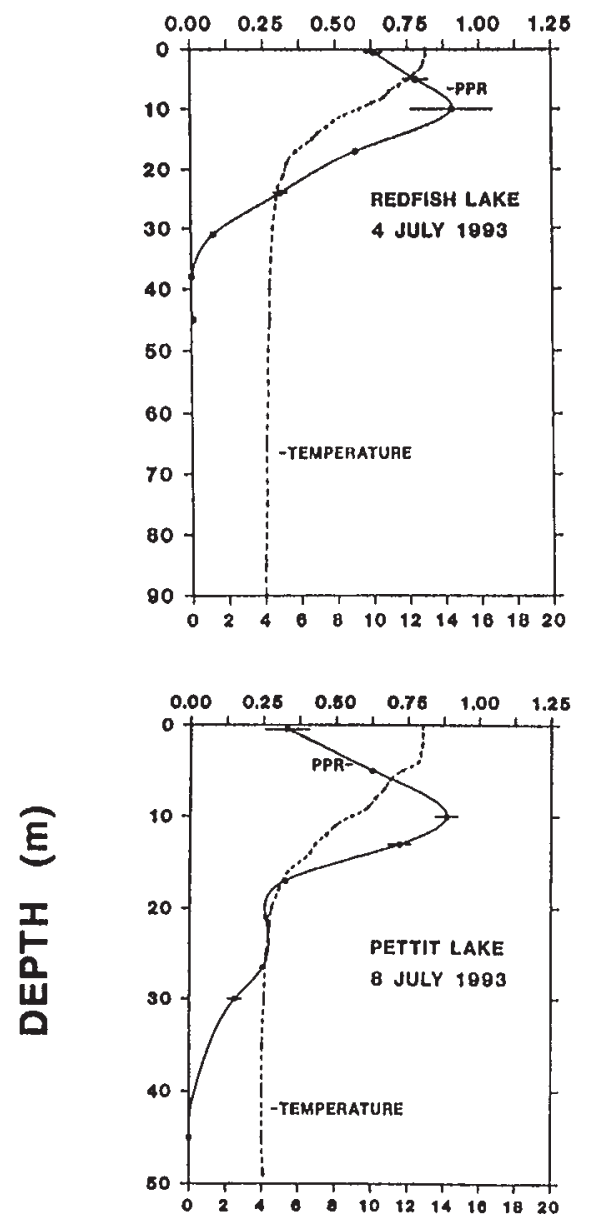

$\left(\mathrm{mg} \mathrm{C} \cdot \mathrm{m}^{-3} \cdot \mathbf{h}^{-1}\right)$
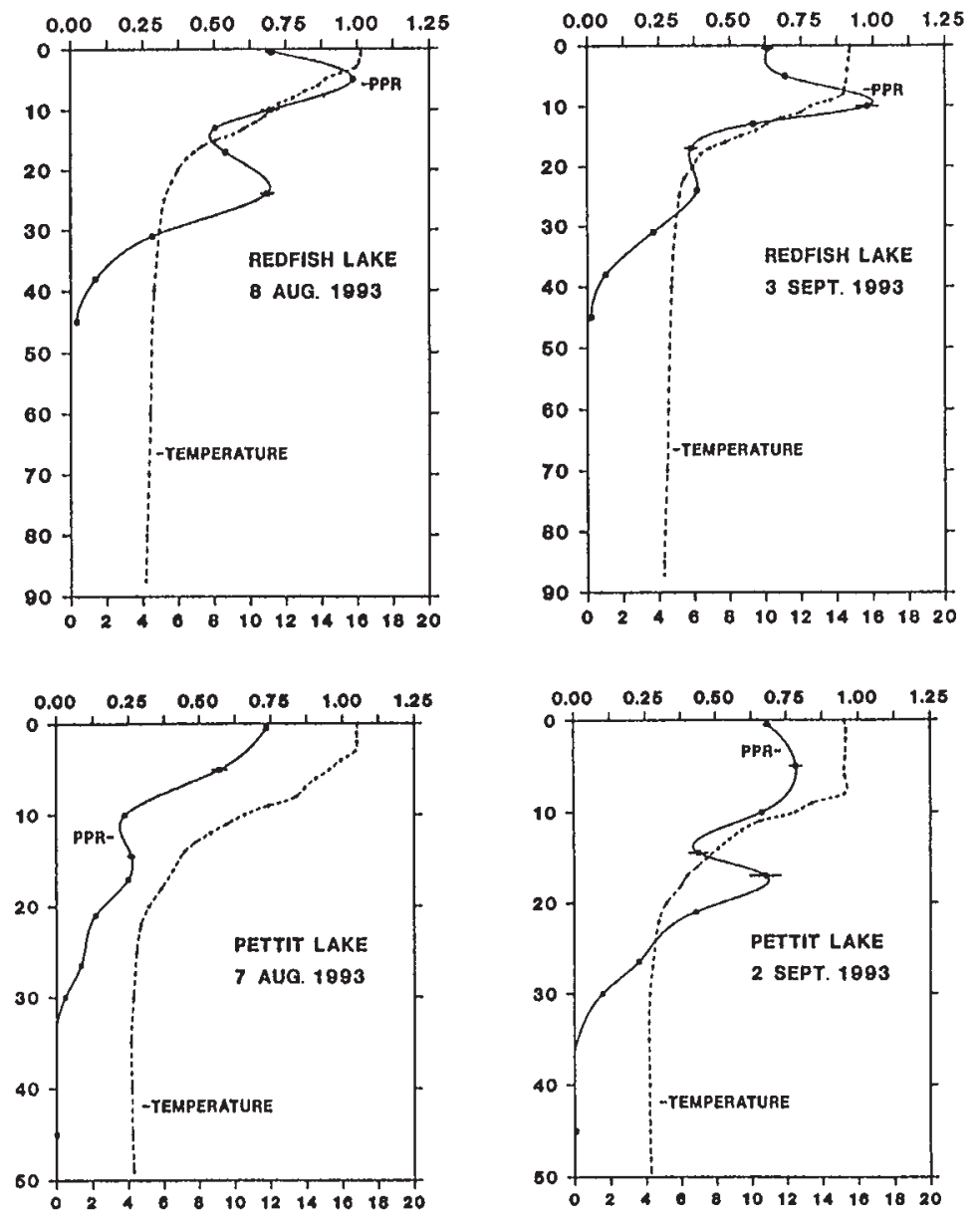
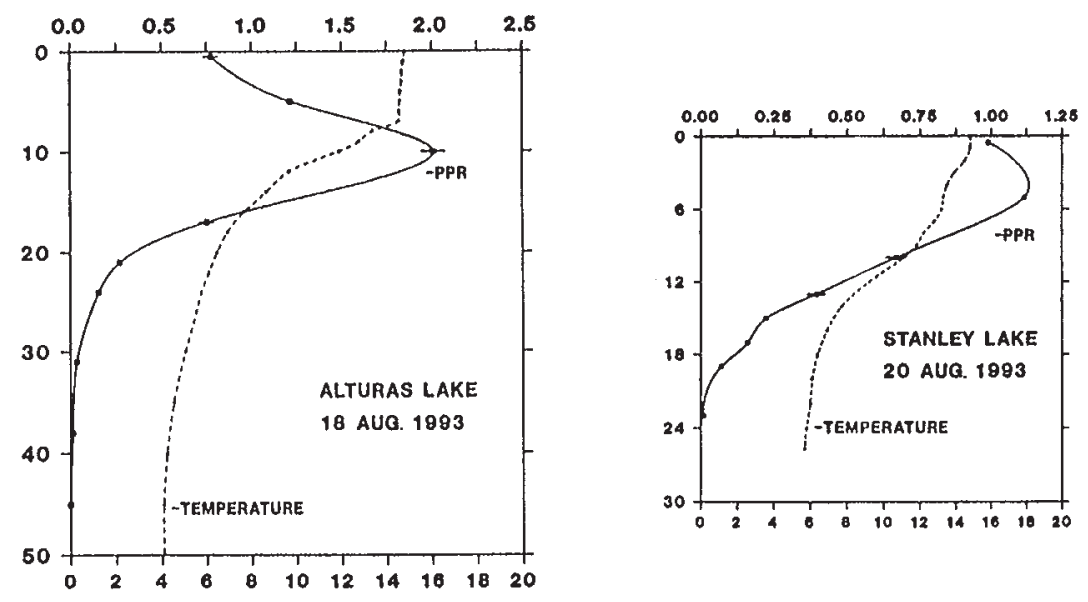

TEMPERATURE ('C) 
Fig. 5. Mean chlorophyll $a(\mu \mathrm{g} / \mathrm{L})$ from epilimnetic tube samples ( $0-6 \mathrm{~m})$ collected from Redfish Lake limnocorrals, 1993. Control (CNTL), low, and high fertilization treatments are shown. Lake epilimnetic chlorophyll $a(\mu \mathrm{g} / \mathrm{L})$ is also shown for comparison. Vertical bars for limnocorrals show ranges $(n=2)$.

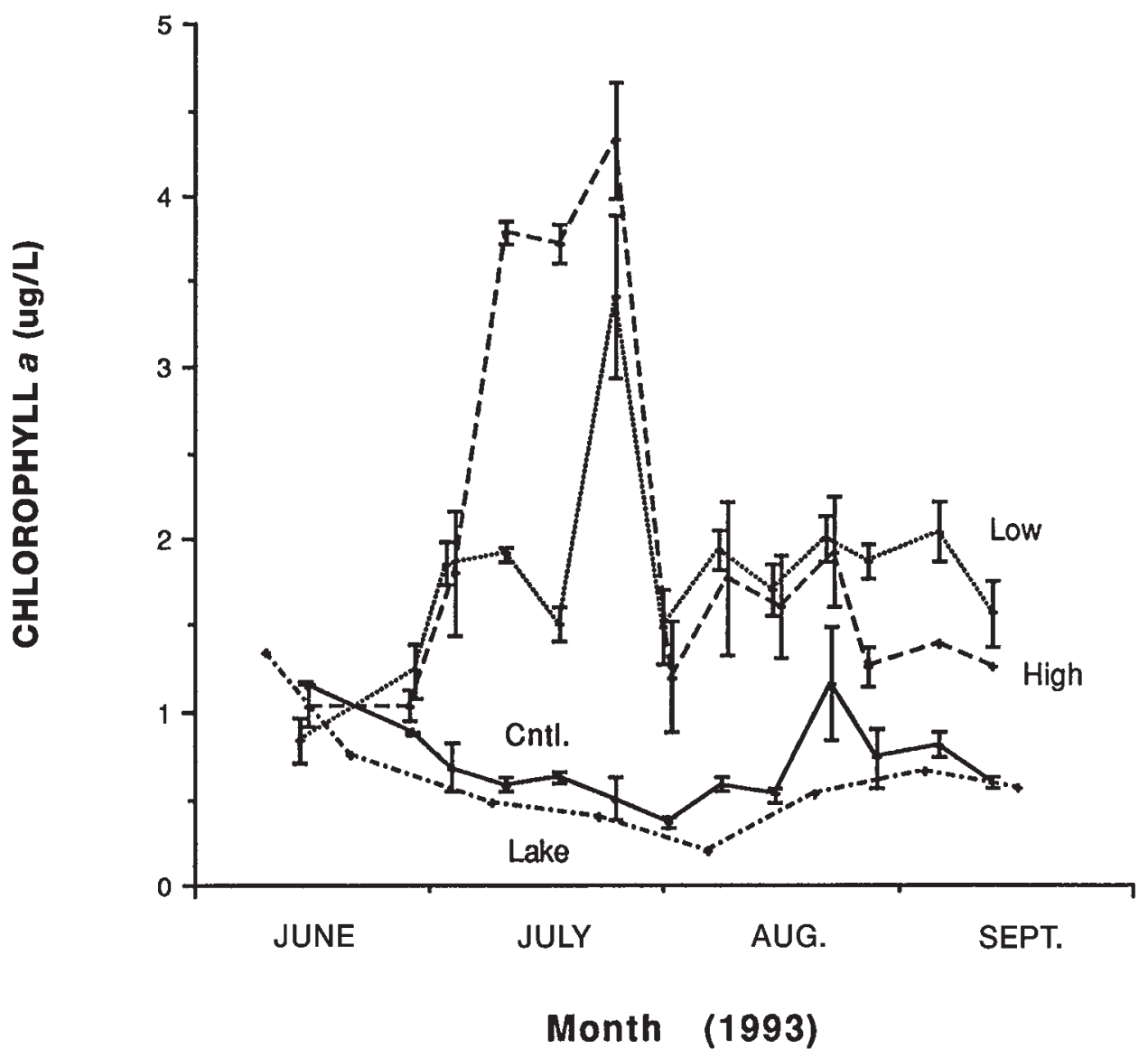

The seasonal progression of epilimnetic chlorophyll $a$ in the Sawtooth Valley lakes in 1993 was similar to that of Redfish Lake: the highest values for the ice-free season occurred just after spring overturn in May, followed by a gradual decline to a midsummer minimum, after which levels increased (Fig. 2). At the 1\% light level, however, chlorophyll $a$ increased irregularly after spring overturn in each lake (as exemplified by Redfish Lake in Fig. 2; also see Gross (1995) for similar figures for the other Sawtooth Valley lakes).

Not only were chlorophyll $a$ concentrations higher near the $1 \%$ light level, but greater algal biovolumes were supported there as well (Fig. 3). In Redfish Lake, for example, biovolumes were on the average $170 \%$ greater at the $1 \%$ light level than in the epilimnion.

Diatoms (Synedra, Cyclotella, Melosira, and Tabellaria) and Dinobryon sp. dominated the lake's epilimentic biovolume early in the growing season. By late July, however, the diatoms declined in the epilimnia, and were replaced by chlorophytes and dinophytes, particularly Peridinium (Fig. 3). Cyanobacteria were rare in all lakes $(<3 \%$ of mean summer epilimnetic biovolume) except in Alturas, where they were present but nondominant (13\%).

In Redfish Lake, the chrysophyte Dinobryon sp. and the diatoms Synedra sp. and Tabellaria sp. made up a considerable portion of the biovolume of the deep algal stratum (Fig. 3). Diatom and Dinobryon sp. peaks occurred later in the
DCM than in the epilimnion. In the other Sawtooth Valley lakes, the deep algal stratum consisted primarily of Oocystis and Chlorella spp. (Gross 1995).

Rates of primary production in the Sawtooth Valley lakes were very low, with most of the production occurring below the epilimnion. Integrated water column productivity ranged from 9 to $27 \mathrm{mg} \mathrm{C} \cdot \mathrm{m}^{-2} \cdot \mathrm{h}^{-1}$ on the eight occasions it was measured. In Redfish Lake, $68-72 \%$ of the primary production occurred below the epilimnion. In the other Sawtooth Valley lakes, except Stanley, $\geq 62 \%$ of the primary production occurred below the epilimnia (Fig. 4). Because of Stanley Lake's shallower depth and smaller non-epilimnetic photic volume, most of the PPR (64\%) occurred in its epilimnion. Photosynthesis was measurable in all lakes to depths of at least $30 \mathrm{~m}$, except in Stanley Lake, which is only $26 \mathrm{~m}$ deep (Table 1).

The primary production peak usually occurred near the top of the thermocline at depths of 5-10 m (Fig. 4). Lowered productivity at the surface (photoinhibition) was observed in all profiles, except for Pettit Lake on 7 August, which was an overcast, stormy day. Secondary peaks in productivity in the metalimnion were found on two of three dates in Redfish Lake, and on all three dates we made measurements in Pettit Lake. In Alturas and Stanley lakes, secondary peaks in productivity were absent on the days measurements were taken, but both analyses were done on partially cloudy days. 
Fig. 6. Vertical profiles of $(a-c)$ mean chlorophyll $a(\mu \mathrm{g} / \mathrm{L})$ and $(d-f)$ primary productivity $\left(\mathrm{mg} \mathrm{C}^{-3} \cdot \mathrm{m}^{-3} \cdot \mathrm{h}^{-1}\right)$ in the Redfish Lake limnocorrals, 1993. Control (CNTL), low, and high fertilization treatments are shown; horizontal bars show ranges $(n=2)$.

\section{CHLOROPHYLL a $(\mu \mathrm{g} / \mathrm{L})$}
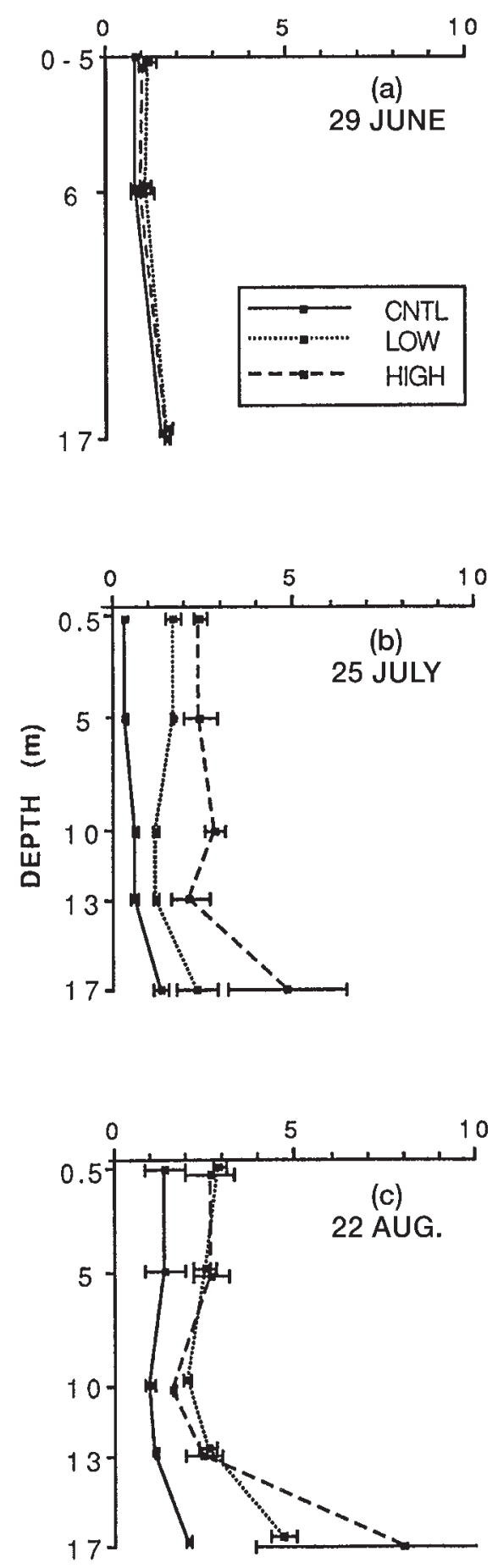

Limnocorral experiment

Nutrient additions to the limnocorrals caused a significant increase in chlorophyll (repeated measures ANOVA, $F_{2,3}=57.8$, $p=0.004$ ). The means (and ranges) of the weekly epilimnetic chlorophyll levels were 0.65 (0.36-1.16), 1.94 (1.49-3.41), and $2.19(1.20-4.32) \mu \mathrm{g} / \mathrm{L}$ for the CNTL, LOW, and HIGH
PRIMARY PRODUCTIVITY $\left(\mathrm{mg} \mathrm{C} \cdot \mathrm{m}^{3} \cdot \mathrm{h}^{-1}\right)$
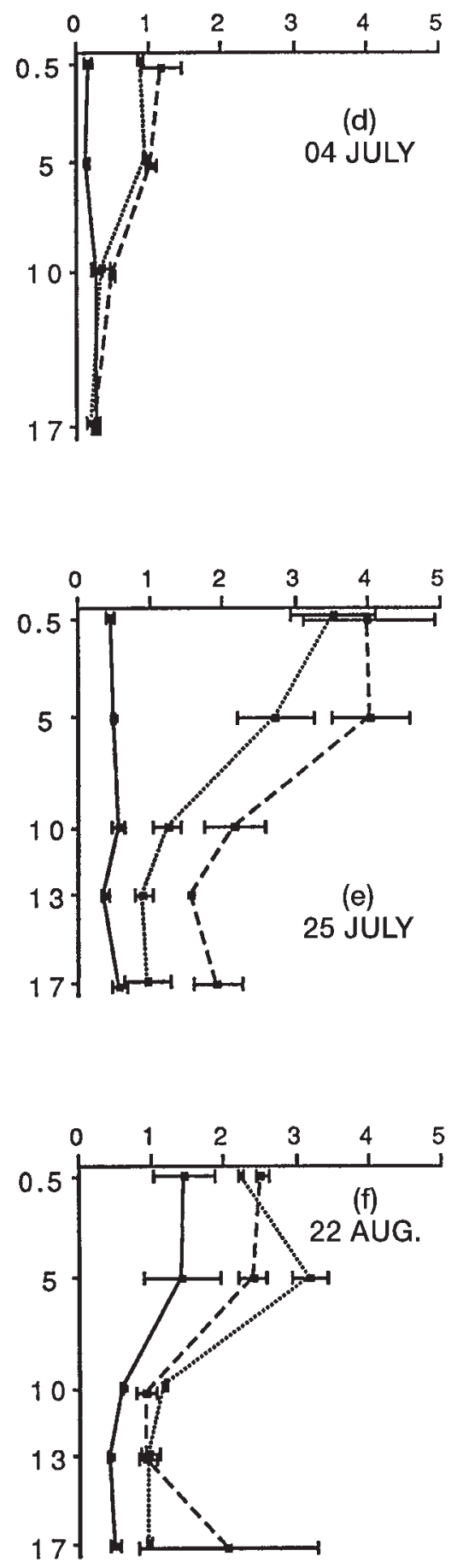

treatments, respectively (Fig. 5). Although there was an overall significant treatment effect, the LOW and HIGH means were not significantly different from each other (post hoc Tukey's comparison, $\alpha=0.05$ ). The epilimnetic chlorophyll levels in the CNTL treatments followed a trend similar to, although slightly higher than, the lake during the experiment (Fig. 5). 
Fig. 7. Mean Secchi depth $(n=2)$ by treatment in the Redfish Lake limnocorrals for the duration of the experiment. Control (CNTL), low, and high fertilization treatments are shown.

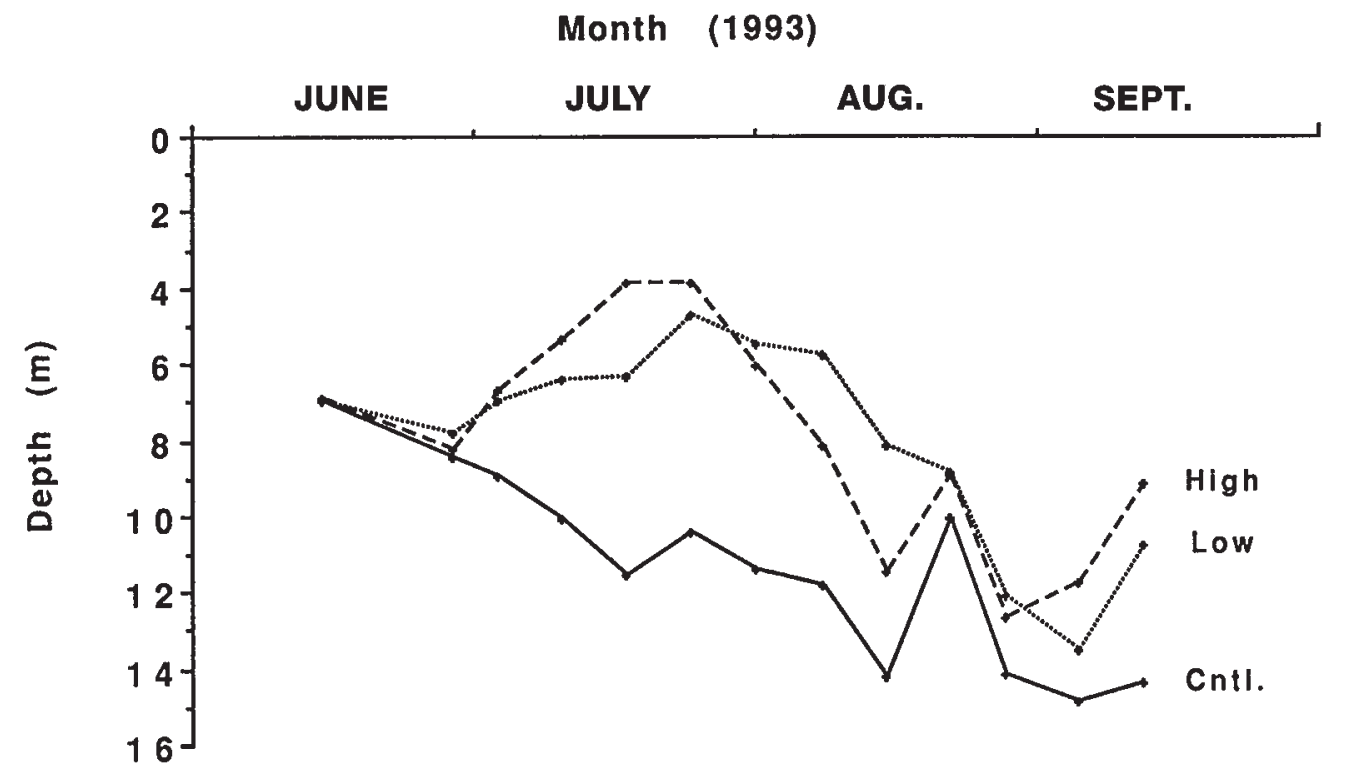

The nutrient additions caused increased chlorophyll at all depths, particularly at $17 \mathrm{~m}$ (Figs. $6 a-6 c)$. The high concentrations at $17 \mathrm{~m}$ may have been an artifact of the 17-m depth boundary imposed by the limnocorral bottoms. Samples collected from $17 \mathrm{~m}$ may have contained some phytoplankton that had sedimented out of the water column.

Nutrient additions to the limnocorrals significantly stimulated primary production (repeated measures ANOVA, $F_{2,3}=$ 75.6, $p=0.003$ ). Fertilization significantly increased epilimnetic production more than metalimnetic production (Figs. 6d-6f) (repeated measures ANOVA, $F_{3,9}=19.9, p<$ 0.001). Six days after the experiment began (4 July), increased production in the epilimnia of both the LOW and HIGH treatments was apparent (ANOVA, $F_{2,3}=9.16, p=0.053$ ). Metalimnetic production rates, however, were similar in the control and fertilized treatments. Three weeks later (25 July), epilimnetic production was further stimulated in both the LOW and HIGH treatments (ANOVA, $F_{2,3}=146, p=0.001$ ), and the effects extended into the metalimnia. After four additional weeks (22 August), primary production was still enhanced by the nutrient additions (ANOVA, $F_{2,3}=8.82, p=$ $0.055)$, but the differences among treatments were less distinct.

When we integrated the phytoplankton productivity profiles through the water column, we found that nutrient additions significantly increased primary production by $110-290 \%$ in the LOW treatment, and by $90-490 \%$ in the HIGH (repeated measures ANOVA, $\left.F_{2,3}=51.1, p=0.005\right)$. A post hoc Tukey's comparison, however, showed that the increases in primary productivity resulting from the LOW and HIGH treatments were not significantly different from each other $(\alpha=$ $0.05)$.

Water transparency, as measured by Secchi depth, was significantly decreased by the nutrient additions (repeated measures ANOVA, $\left.F_{2,3}=57.6, p=0.004\right)$. The means of the weekly Secchi depth measurements were 11.3, 8.0, and $7.9 \mathrm{~m}$ for the CNTL, LOW, and HIGH treatments, respectively (Fig. 7). The LOW and HIGH Secchi means were significantly
Table 3. Mean light extinction coefficients, percentage of surface light at $17 \mathrm{~m}$ depth, and percentage shading in nutrient treatments (LOW and HIGH) compared with the control (CNTL) treatments for the Redfish Lake limnocorrals, 1993.

\begin{tabular}{|c|c|c|c|}
\hline Treatment & $\begin{array}{l}\text { Mean light } \\
\text { extinction } \\
\text { coefficient }\end{array}$ & $\begin{array}{c}\% \text { of surface } \\
\text { light at } 17 \mathrm{~m} \\
\text { depth }\end{array}$ & $\begin{array}{l}\% \text { less light at } \\
17 \mathrm{~m} \text { than in } \\
\text { CNTL treatment }\end{array}$ \\
\hline \multicolumn{4}{|c|}{ 4 July $1993(p=0.697)$} \\
\hline CNTL & $0.241 a$ & 1.68 & - \\
\hline LOW & $0.247 a$ & 1.53 & 9 \\
\hline HIGH & $0.237 a$ & 1.81 & -8 \\
\hline \multicolumn{4}{|c|}{11 July $1993(p=0.264)$} \\
\hline CNTL & $0.242 a$ & 1.69 & - \\
\hline LOW & $0.266 a$ & 1.10 & 35 \\
\hline HIGH & $0.268 a$ & 1.06 & 37 \\
\hline \multicolumn{4}{|c|}{25 July $1993(p=0.068)$} \\
\hline CNTL & $0.188 a$ & 4.17 & - \\
\hline LOW & $0.223 b$ & 2.27 & 46 \\
\hline $\mathrm{HIGH}$ & $0.221 b$ & 2.48 & 41 \\
\hline \multicolumn{4}{|c|}{9 August $1993(p=0.080)$} \\
\hline CNTL & $0.197 a$ & 3.53 & - \\
\hline LOW & $0.221 b$ & 2.36 & 33 \\
\hline HIGH & $0.212 a b$ & 2.76 & 22 \\
\hline
\end{tabular}

\footnotetext{
Note: Light extinction coefficients followed by the same letter were not significantly different (Tukey's post hoc comparison with $\alpha=0.10$ ). The $p$ values for the dates are from ANOVAs $(\mathrm{df}=2)$ for each date (Gross 1995).

different from the CNTL Secchi mean but not significantly different from each other (post hoc Tukey's comparison, $\alpha=$ $0.05)$.

The LOW and HIGH treatments had $22-46 \%$ less light available at $17 \mathrm{~m}$ depth than did the CNTL treatments on 11 July, 25 July, and 9 August (Table 3). When using a post hoc Tukey's comparison and $\alpha=0.10$, these differences in light were significantly different for 25 July $(p=0.07)$ and
} 
Fig. 8. Relationship between irradiance $\left(I_{z}\right)$ and photosynthetic rates normalized to chlorophyll $a(\mathrm{CHL} a)\left(P_{z}\right)$ from six 1993 dates in the Sawtooth Valley lakes. The curve in $a$ was fit through data points measured below the bottom of the thermocline using the method of Neale and Richerson (1987). The curve in $b$ was fit through data points measured above the bottom of the thermocline using the method of Jassby and Platt (1976). The curves were used to predict primary production depth profiles under fertilized and unfertilized conditions in Redfish Lake. Data are from Gross (1995).
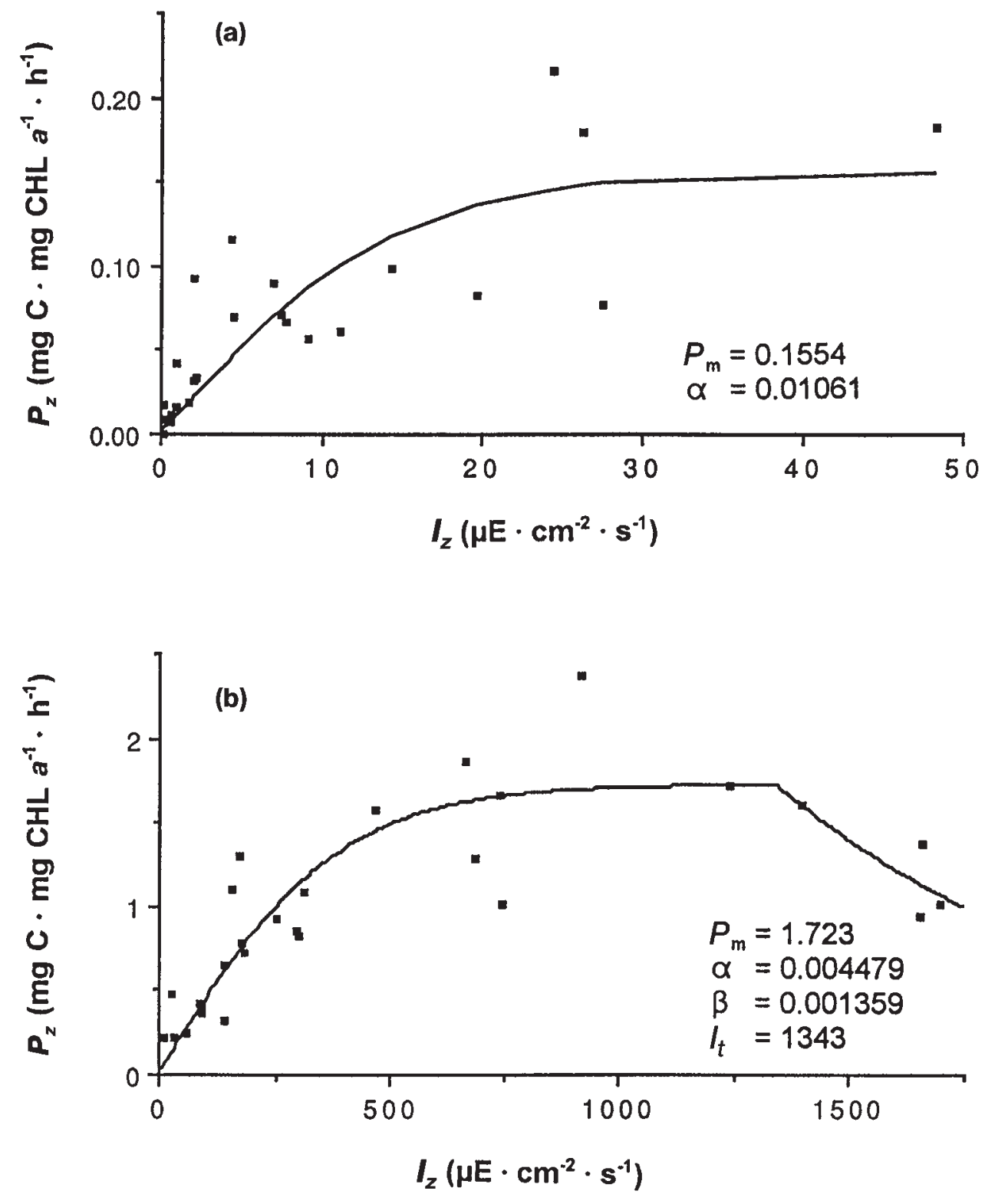

9 August $(p=0.08)$, but not for 11 July $(p=0.26)$. Measurement of the light profiles was problematic owing to shading caused by infrastructure supporting the limnocorrals (e.g., docks, float tubes, sampling platforms), and this contributed to the variability in the light data. Nevertheless, it is apparent from the light, Secchi, and chlorophyll data that substantial shading was caused in the limnocorrals by the nutrient additions.

\section{Primary productivity predictions}

The results of the lake sampling, the limnocorral experiment, and the $P-I$ curves (Fig. 8 ) were used to predict primary production $(\mathrm{PPR})$ depth profiles under fertilized and unfertilized conditions for two dates in Redfish Lake (Fig. 9). The predictions were made using a range of light extinction coefficients from Table 3. By using a range of light coefficients in eq. 3, the sensitivity of this modelling approach to different levels of shading was tested. A low level of shading in the fertilized versus unfertilized scenario was modelled using $\operatorname{LE}_{\text {high }}(0.212)$ and $\mathrm{LE}_{\text {cntl }}(0.197)$ from 9 August 1993; intermediate shading was modelled using $\mathrm{LE}_{\text {low }}(0.221)$ and $\mathrm{LE}_{\text {cntl }}$ (0.197) from 9 August 1993; high shading was modelled using $\mathrm{LE}_{\text {low }}$ (0.223) and $\operatorname{LE}_{\text {cntl }}(0.188)$ from 25 July 1993. Under the low, intermediate, and high shading scenarios, 22, 33, and 46\% less light, respectively, was available at the $17-\mathrm{m}$ depth in the fertilized versus unfertilized scenario. 
Fig. 9. Primary production profiles for Redfish Lake on two dates in 1993. ( $a$ and $b$ ) Observed and predicted primary production $(P)$ profiles under fertilized and unfertilized conditions using intermediate shading levels. ( $c$ and $d$ ) Chlorophyll $a$ concentrations observed in the lake under unfertilized conditions and predicted for fertilized conditions. ( $e$ and $f$ ) Light levels $\left(I_{z}\right)$ observed in the lake under ambient conditions and predicted for fertilized conditions under intermediate shading levels.
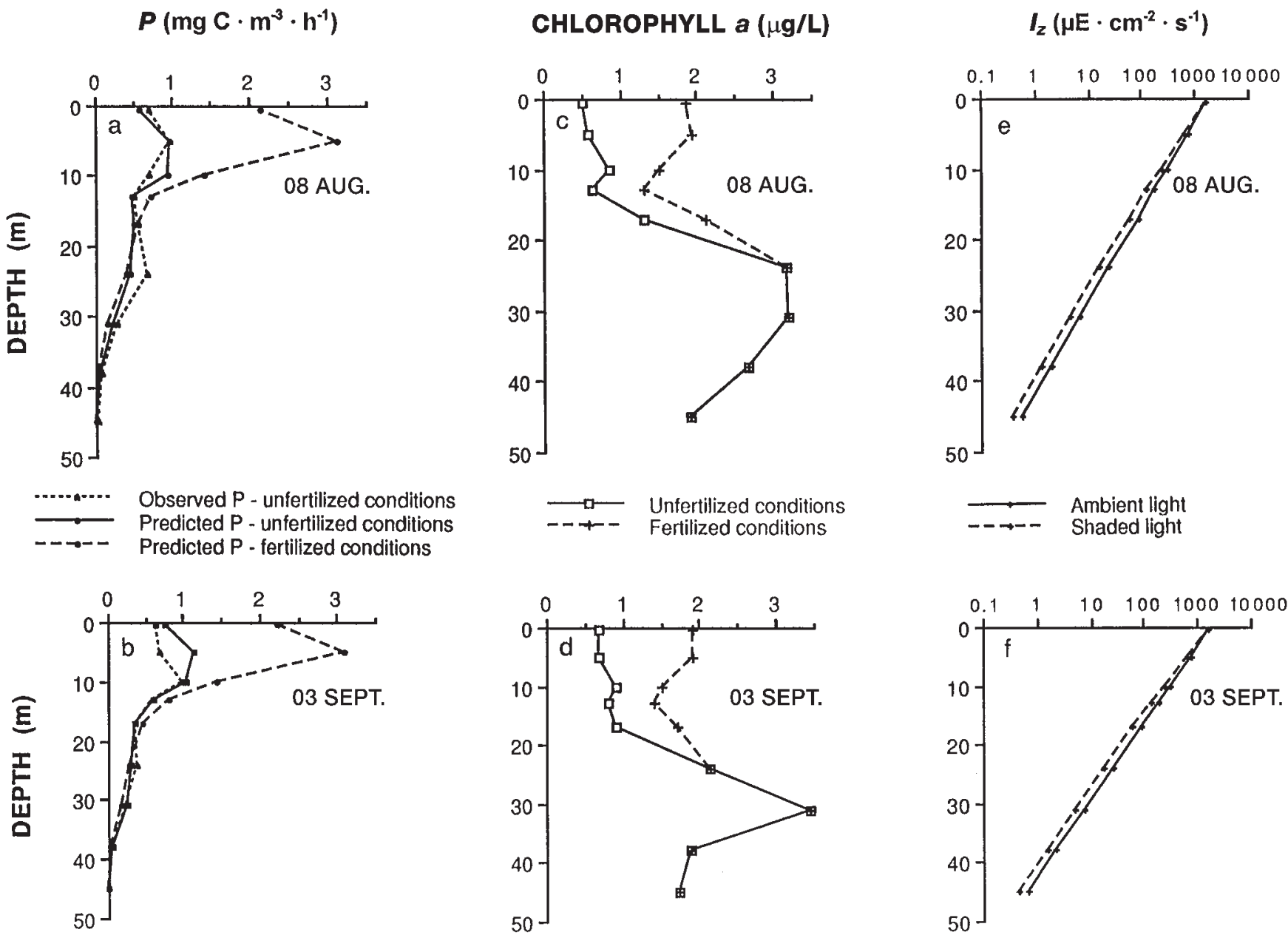

The simulations demonstrated a large increase in epilimnetic PPR owing to fertilization and only a slight decrease in production in the deeper strata because of self-shading (Fig. 9). Depending on the level of shading used, the simulations predicted integrated water column PPR for fertilized conditions to be $183-201 \%$ of predicted PPR for unfertilized conditions for 8 August and $175-190 \%$ for 3 September. Predicted integrated PPR for unfertilized conditions was 91 and $117 \%$, respectively, of the actual PPR observed in the lake on 8 August and 3 September.

\section{Discussion}

Our results demonstrate that there are broad DCM in the Sawtooth Valley lakes and that higher phytoplankton biovolumes are present in these DCM than in the lake's epilimnetic waters. Furthermore, these deeper waters contribute over $60 \%$ of the primary productivity in the lakes.

The limnocorral experiment demonstrated that lake fertilization at the levels tested would decrease water clarity and increase shading of the DCM, thus compressing the photic zone. However, our modelling indicated that the resulting loss of primary production in the DCM under these fertilized conditions would be more than offset by higher productivity in the epilimnion. Primary production in the $17-\mathrm{m}$ water column of the treated limnocorrals was $90-490 \%$ greater than that in the controls.

Compression of the photic zone in association with cultural eutrophication has been documented in other lakes. Coastal British Columbian sockeye-rearing lakes that received nutrient additions had shallower Secchi depths than unfertilized lakes (Stockner 1987). Goldman (1988) showed that water transparency decreased and the photic zone compressed during the onset of cultural eutrophication of ultra-oligotrophic Lake Tahoe. He also found that water column primary productivity rates increased as Secchi depth decreased.

For lake fertilization to help in the recovery of the Snake River sockeye salmon, nutrient additions must stimulate the zooplankton that occupy waters in which sockeye salmon reside, thus allowing the energy captured in increased PPR to be transferred to the juvenile sockeye. Because juvenile sockeye often avoid water temperature $>16^{\circ} \mathrm{C}$ (Foerster 1968), Shortreed and Stockner (1990) concluded that the effectiveness of surface fertilization of Sproat Lake (a British Columbia lake 
with a DCM) might be reduced because the zooplankton there did not display diel vertical migrations. Thus, the epilimnetic zooplankton that would benefit from nutrient additions would not be available to the juvenile sockeye. These concerns are less applicable to Redfish Lake. The distribution of zooplankton in Redfish Lake's water column suggests that they may be able to convey energy gains resulting from epilimnetic nutrient additions to juvenile sockeye (Steinhart et al. 1994). Also, epilimnetic temperatures in Redfish Lake exceeded $16^{\circ} \mathrm{C}$ for a much shorter period of the year than in Sproat Lake, and thus the epilimnetic zooplankton should be more available to the sockeye salmon.

An approach that might circumvent spatial and temporal concerns about juvenile sockeye habitation of the water column is to inject nutrient additions into deeper waters (metalimnetic fertilization) (LeBrasseur et al. 1978; Gross 1995). This approach may be more effective than surface fertilization in facilitating sockeye growth.

Although our studies were not specifically designed to isolate mechanisms responsible for the DCM's presence, we may have identified a factor contributing to their maintenance in the Sawtooth Valley lakes. With the onset of thermal stratification following spring overturn in 1993, stream inflow temperatures (automatically logged every $36 \mathrm{~min}$ ) were almost always colder than lake epilimnetic temperatures (H.P. Gross and W.A. Wurtsbaugh, unpublished data). Based on temperature, we estimated that the inflow water would plunge to the meta- or hypo-limnion during most of the ice-free season. Diel fluctuations in the stream temperatures indicated that the entering stream water may plunge across a wide range of depths on a given day. Fluoroscene dye tracer studies in the Sawtooth Valley lakes have confirmed the plunging inflow phenomenon (W.A. Wurtsbaugh, unpublished data), although dye entering the lake did not plunge as deeply as temperature alone would predict. Nevertheless, it appears that nutrients brought into the lake through inflow streams during the ice-free stratified period (the primary nutrient input source to lakes during this time) are first delivered to metalimnetic and hypolimnetic waters. This may result in higher nutrient concentrations in these deeper waters than in the lakes' epilimnetic waters, thus contributing to the maintenance of the DCM.

During the second half of our limnocorral experiment, the HIGH treatments did not significantly influence primary productivity, epilimnetic chlorophyll $a$, or Secchi depth more than did the LOW treatments $(p>0.5)$. These results were unexpected but may have been caused by differences in periphyton between the LOW and HIGH treatments. Periphyton chlorophyll $a$ in the HIGH treatments was $90-720 \%$ greater than in the LOW treatments (Budy et al. 1994). The periphyton growth in the HIGH treatments most likely deprived the phytoplankton of more added nutrients than did periphyton in the LOW treatments, thus diminishing the difference in primary productivity between the two treatments.

In conclusion, decreases in light and increases in primary production should be expected as a result of fertilization of ultra-oligotrophic, dimictic Redfish Lake. Decreased PPR in the DCM would be more than offset by increased PPR in the epilimnetic waters. For lake fertilization to be used as a tool to assist in the Snake River sockeye salmon recovery effort, energy captured in increased PPR must be effectively transferred to the zooplankton, and ultimately to the juvenile sockeye salmon, without causing adverse effects on the aquatic community and trophic structure of the Sawtooth Valley lakes.

\section{Acknowledgments}

We are indebted to the following people for contributing to this work: T. Blenckner, G. Steinhart, S. Durham, D. Staab, D. Hunter, N. Bouwes, N. Roberts, and J. Ruzycki. P. Neale provided data and advice. Funding was provided through the Shoshone-Bannock Indian Tribes (from the Bonneville Power Administration), a Vice-Presidential Fellowship from Utah State University, and the Ecology Center at Utah State University. In addition, we would like to acknowledge invaluable logistic support from C. Draper and the staff of the Stanley Ranger Station (Sawtooth National Recreation Area) and the Sawtooth Fish Hatchery (Idaho Fish and Game).

\section{References}

Anderson, G.C. 1969. Subsurface chlorophyll maximum in the northeast Pacific Ocean. Limnol. Oceanogr. 14: 386-391.

Beauchamp, D.A., Budy, P.E., Wurtsbaugh, W.A., Gross, H.P., Luecke, C., and Spaulding, S. 1993. Hydroacoustic assessment of fish abundance in Sawtooth Valley lakes. In Snake River sockeye salmon (Oncorhynchus nerka) habitat/limnologic research-annual report 1992. Edited by S. Spaulding. Publ. No. DOE/BP22548-1. U.S. Department of Energy, Bonneville Power Administration, Portland, Oreg. pp. 53-71.

Bevan, D., Harville, J., Bergman, P., Bjornn, T., Crutchfield, J., Klingerman, P., and Litchfield, J. 1994. Snake River salmon recovery team: final recommendations to National Marine Fisheries Service. National Marine Fisheries Service, Portland, Oreg.

Budy, P., Luecke, C., Wurtsbaugh, W.A., and Gross, H.P. 1994. Effects of nutrient enhancement on plankton and the growth of juvenile salmon in Redfish Lake. In Snake River sockeye salmon habitat and limnological research — annual report 1993. Edited by D. Tuescher, D. Taki, W.A. Wurtsbaugh, C. Luecke, P. Budy, H.P. Gross, and G. Steinhart. Publ. No. DOE/BP-22548-2. U.S. Department of Energy, Bonneville Power Administration, Portland, Oreg. pp. 62-77.

Budy, P., Luecke, C., Wurtsbaugh, W.A., Gross, H.P., and Gubala, C. 1995. Limnology of the Sawtooth Valley lakes with respect to potential growth of juvenile Snake River sockeye salmon. Northwest Sci. 69: 33-150.

Crumpton, W.G. 1987. A simple and reliable method for making permanent mounts of phytoplankton for light and fluorescence microscopy. Limnol. Oceanogr. 32: 1154-1159.

Fee, E.J. 1976. The vertical and seasonal distribution of chlorophyll in lakes of the Experimental Lakes Area, northwestern Ontario: implications for primary production estimates. Limnol. Oceanogr. 21: 767-783.

Foerster, R.E. 1968. The sockeye salmon, Oncorhynchus nerka. Bull. Fish. Res. Board Can. No. 162.

Goldman, C.R. 1988. Primary productivity, nutrients, and transparency during the early onset of eutrophication in ultra-oligotrophic Lake Tahoe, California-Nevada. Limnol. Oceanogr. 33: $1321-1333$.

Gross, H.P. 1995. Evaluation of lake fertilization as a tool to assist in the recovery of the Snake River sockeye salmon. M.S. thesis, Utah State University, Logan, Utah.

Gross, H.P., Wurtsbaugh, W.A., Luecke, C., and Budy, P. 1994. Comparison of epilimnetic and metalimnetic fertilizations on the phytoplankton and zooplankton in Pettit Lake, Idaho. In Snake River sockeye salmon habitat and limnological research — annual report 1993. Edited by D. Tuescher, D. Taki, W.A. Wurtsbaugh, 
C. Luecke, P. Budy, H.P. Gross, and G. Steinhart. Publ. No. DOE/BP-22548-2. U.S. Department of Energy, Bonneville Power Administration, Portland, Oreg. pp. 78-99.

Hobson, L.A., and Lorenzen, C.J. 1972. Relationship of chlorophyll maxima to density structure in the Atlantic Ocean and Gulf of Mexico. Deep-Sea Res. 19: 297-306.

Holm-Hansen, O., and Riemann, B. 1978. Chlorophyll $a$ determination: improvements in methodology. Oikos, 30: 438-447.

Jassby, A.D., and Platt, T. 1976. Mathematical formulation of the relationship between photosynthesis and light for phytoplankton. Limnol. Oceanogr. 21: 540-547.

Kiefer, D.A., Olson, R.J., and Holm-Hansen, O. 1976. Another look at the nitrite and chlorophyll maxima in the central North Pacific. Deep-Sea Res. 23: 1199-1208.

Kyle, G.B., Koenings, J.P., and Barret, B.M. 1988. Density-dependent, trophic level responses to an introduced run of sockeye salmon (Oncorhynchus nerka) at Frazer Lake, Kodiak Island, Alaska. Can. J. Fish. Aquat. Sci. 45: 856-867.

LeBrasseur, R.J., McAllister, C.D., Barraclough, W.E., Kennedy, O.D., Manzer, J., Robinson, D., and Stephens, K. 1978. Enhancement of sockeye salmon (Oncorhynchus nerka) by lake fertilization in Great Central Lake: summary report. J. Fish. Res. Board Can. 35: 1580-1596.

Luecke, C., Budy, P., Wurtsbaugh, W.A., Gross, H.P., and Steinhart, G. 1996. Simulated growth and production of endangered Snake River sockeye salmon: assessing lake management strategies for nursery lakes. Fisheries (Bethesda), 21(6): 18-25.

Moll, R.A., and Stoermer, E.F. 1982. A hypothesis relating trophic status and subsurface chlorophyll maxima of lakes. Arch. Hydrobiol. 94: 425-440.

Neale, P.J., and Richerson, P.J. 1987. Photoinhibition and the diurnal variation of phytoplankton photosynthesis-I. Development of a photosynthesis-irradiance model from studies of in situ response. J. Plankton Res. 9: 167-193.

Platt, T., Harrison, W.G., Irwin, B., Horne, E.P., and Gallegos, C.L.
1982. Photosynthesis and photoadaptation of marine phytoplankton in the Arctic. Deep-Sea Res. 29: 1159-1170.

Reynolds, C.S. 1984. The ecology of freshwater phytoplankton. Cambridge University Press, Cambridge, England.

SAS Institute Inc. 1988. SAS/STAT user's guide, release 6.03 edition. SAS Institute Inc., Cary, N.C.

Schindler, D.W. 1977. Evolution of phosphorous limitation in lakes. Science (Washington, D.C.), 195: 260-262.

Shortreed, K.S., and Stockner, J.G. 1990. Effect of nutrient additions on lower trophic levels of an oligotrophic lake with a seasonal deep chlorophyll maximum. Can. J. Fish. Aquat. Sci. 47: 262-273.

Steele, J.H. 1964. A study of production in the Gulf of Mexico. J. Mar. Res. 22: 211-222.

Steinhart, G., Gross, H.P., Budy, P., Luecke, C., and Wurtsbaugh, W.A. 1994. Limnological investigations and hydroacoustic surveys of Sawtooth Valley lakes. In Snake River sockeye salmon habitat and limnological research — annual report 1993. Edited by D. Tuescher, D. Taki, W.A. Wurtsbaugh, C. Luecke, P. Budy, H.P. Gross, and G. Steinhart. Publ. No. DOE/BP-22548-2. U.S. Department of Energy, Bonneville Power Administration, Portland, Oreg. pp. 30-61.

Stockner, J.G. 1987. Lake fertilization: the enrichment cycle and lake sockeye salmon (Oncorhynchus nerka) production. In Sockeye salmon (Oncorhynchus nerka) population biology and future management. Edited by H.D. Smith, L. Margolis, and C.C. Wood. Can. Spec. Publ. Fish. Aquat. Sci. No. 96. pp. 198-215.

Stockner, J.G., and Shortreed, K.S. 1988. Response of Anabaena and Synechococcus to manipulation of nitrogen:phosphorus ratios in a lake fertilization experiment. Limnol. Oceanogr. 33: 1348-1361.

Wetzel, R.G. 1983. Limnology. Saunders College Publishing, New York, N.Y.

Wetzel, R.G., and Likens, G.E. 1991. Limnological analyses. SpringerVerlag, New York, N.Y. 